\title{
An evaluation of the saw, dry and rip process for the conversion of Rubberwood.
}

\begin{abstract}
A study was carried out to compare the volume recovery and product quality of two different sawing techniques in the conversion of rubberwood which is plagued with low yield. The study was undertaken in a sawmill in Peninsular Malaysia, using the conventional live sawing process and the Saw Dry and Rip (SDR) process. The results showed that the SDR process resulted in higher volume recovery as well as higher product quality, compared to the conventional live sawing process. Further, the application of high temperature drying for rubberwood sawn material resulted in lower drying defects and together with the SDR process, resulted in a more economical solution for the conversion of rubberwood. Accordingly, a survey of the current industrial practices as rubberwood 125 saw mills revealed that rubberwood sawmilling is plagued with a low yield of $27 \%$ and the SDR process, if applied offers a significant improvement both in terms of volume recovery as well as product quality. Therefore, the results of this study have far reaching industrial implications on the sawing and machining of rubberwood in the South East Asian region.
\end{abstract}

Keyword: Rubberwood; Saw; Dry; Rip. 